\title{
Ruminal degradability of tropical leguminous plants from eastern Amazonia
}

\section{Degradabilidade ruminal de leguminosas tropicais da Amazônia Oriental}

\author{
Ermino Braga ${ }^{1}$; Ermino Braga Filho ${ }^{2}$; Jamile Andréa Rodrigues da Silva ${ }^{1 *}$; Cristian \\ Faturi $^{1}$; Felipe Nogueira Domingues ${ }^{1}$; José de Brito Lourenço Júnior ${ }^{3}$
}

\begin{abstract}
The aim of this study was to evaluate ruminal degradation of dry matter (DM), crude protein (CP), and neutral detergent fiber (NDF) of Cratylia argentea, Flemingia macrophylla (Willd.) Merrill, and Stylosanthes guianensis 'Campo Grande' (EMBRAPA), aged 55 and 75 days, in sheep with rumen cannulas, using the in-situ technique. A factorial design of 3 leguminous plants $\times 2$ ages $\times 6$ incubation times was used, totaling 36 experimental units. The experimental period included 14 days for adaptation to diet and 5 days for data collection. Cratylia at both ages and Flemingia aged 55 days showed the highest "a" fraction values for DM degradability. Cratylia aged 55 days and Stylosanthes at both ages showed the highest "a" fraction values for CP. The highest "b" fraction value for DM was $51.27 \%$ for Stylosanthes aged 55 days. This rate was lower for the other leguminous plants, especially for Flemingia at both ages. The "b" fraction values for NDF are considered low for Flemingia, what may be the result of lower ruminal degradation. The highest "c" fraction degradation rate for DM was observed in all leguminous plants studied aged 75 days. The highest "c" fraction value for CP was $14.84 \%$ for Stylosanthes aged 75 days. The highest Kd fraction values for DM, NDF, and CP were found in Flemingia. Cratylia, and Stylosanthes aged 75 days presented higher effective degradability (ED) values for DM at 2 and 5\%/hour compared to Flemingia at both ages. Cratylia and Stylosanthes had the highest ED values for NDF, regardless of their passage rates. Stylosanthes presented higher $\mathrm{ED}$ values for $\mathrm{CP}$ at both ages, regardless of its passage rate. The highest DM, NDF, and CP potential degradability (PD) was obtained for Cratylia and Stylosanthes, at both ages. The leguminous plants Cratylia and Stylosanthes can be recommended for use as a protein bank and supplementation for ruminants, whereas, Flemingia macrophylla should not be used as a protein supplement for ruminants, because it contains high levels of fibrous fractions.
\end{abstract}

Key words: Degradation. Crude protein. Dry matter. Neutral detergent fiber.

\section{Resumo}

Objetivou-se avaliar os parâmetros relativos a degradação ruminal da matéria seca (MS), da proteína bruta (PB) e da fibra em detergente neutro (FDN) contidas nas amostras de leguminosas Cratylia argentea, Flemingia macrophylla (Willd) Merril e Stylosanthes guyanensis cv Campo Grande (EMBRAPA), com idades de 55 e 75 dias, em ovinos com cânulas ruminais, pela técnica "in situ".

1 Profs. Drs., Instituto de Saúde e Produção Animal, Universidade Federal Rural da Amazônia, ISPA/UFRA, Belém, PA, Brasil. E-mail: erminobraga@terra.com.br; jamileandrea@yahoo.com.br; cristian.faturi@ufra.edu.br; felipend@gmail.com

2 Médico Veterinário, Fiscal Agropecuário, Agência de Defesa Agropecuária do Estado do Pará, ADEPARA, Belém, Pará, Brasil. E-mail: erminobf@hotmail.com

3 Prof. Dr., Programa de Pós-graduação em Ciência Animal, Universidade Federal do Pará, UFPA, Campus Castanhal, PA, Brasil. E-mail: joselourencojr@yahoo.com.br

* Author for correspondence 
Utilizou-se um arranjo fatorial de 3 leguminosas x 2 idades x 6 tempos de incubação, totalizando 36 unidades experimentais. $\mathrm{O}$ período experimental foi de 14 dias de adaptação à dieta e cinco de coleta de dados. Para a degradabilidade da MS, a Cratylia, em ambas as idades e a Flemingia, com 55 dias, destacaram-se com maior fração "a". Para a fração "a" da PB, as leguminosas Cratylia aos 55 dias e Stylosanthes, de ambas as idades, se destacaram com os maiores valores. O maior valor da fração "b" da MS foi encontrado para a Stylosanthes aos 55 dias, com 51,27\%. Nas demais leguminosas, essa taxa foi menor, destacando-se a Flemingia em ambas as idades. Os valores de fração "b" da FDN da Flemíngia são considerados baixos, deduzindo-se ser de menor degradação no rúmen. A maior taxa de degradação da fração "c" da MS foi observada em todas as leguminosas estudadas na idade de 75 dias. Para a fração "c" da PB, o maior valor foi de 14,84\%, da leguminosa Stylosanthes, de 75 dias. Os maiores valores da fração "kd" da MS, da FDN e da PB foi da Flemingia. Quanto à degradabilidade efetiva (DE) da MS às 2 e 5\%/hora, as leguminosas Cratylia e Stylosanthes, de 75 dias, apresentaram valores superiores em relação à Flemingia, em ambas as idades. Para a DE da FDN, as leguminosas Cratylia e Stylosanthes tiveram os maiores valores, independente da taxa de passagem. A leguminosa Stylosanthes de ambas as idades apresentou maiores valores de $\mathrm{DE}$ da $\mathrm{PB}$, em todas as taxas de passagem apresentadas. A maior degradabilidade potencial da MS, FDN e PB obtida foi para a Cratylia e Stylosanthes, em ambas as idades. As leguminosas Cratylia e Stylosanthes podem ser recomendadas para formação de banco de proteína e suplementação alimentar de ruminantes. Já a Flemingia macrophylla (Willd) Merril, por apresentar elevados teores da frações fibrosas, deve ser evitada como fonte suplementar protéica na dieta de ruminantes.

Palavras-chave: Degradação. Proteína bruta. Matéria seca. Fibra em detergente neutro.

\section{Introduction}

Brazil is the $15^{\text {th }}$ largest sheep producer in the world (FAO, 2014), with a herd of 18.43 million animals (IBGE, 2016). In the Amazon, this herd thrives because the region provides favorable conditions such as radiant energy supply and abundant rainfall, which allow a forage production of satisfactory nutritional value. However, depending on the climatic type, animals may suffer from nutrient deficiencies in pastures, and food supplementation is necessary to obtain acceptable animal performance levels.

The introduction of leguminous forage species in pasture is a feeding alternative for ruminants during the dry season. Leguminous forage plants produce more biomass than herbaceous plants - particularly in humid tropical areas - and are more tolerant to drought, besides being able to regrow and supply good fodder the whole year (MONTEIRO et al., 2009).

\section{Cratylia argentea, Flemingia macrophylla} (Willd.) Merrill, and Stylosanthes guianensis 'Campo Grande' (Embrapa) are leguminous plants with high forage potential. However, it is necessary to investigate their use in animal nutrition, as well as their interaction in animal diets to improve metabolic processes in ruminant production systems. Thus, this study aims to evaluate the potential use of Cratylia argentea, Flemingia macrophylla (Willd.) Merrill, and Stylosanthes guianensis 'Campo Grande' (Embrapa), by assessing their potential and effective ruminal degradability.

\section{Material and Methods}

This experiment was conducted at the Goat and Sheep Research Center of Pará (CPCOP), Federal Rural University of Amazonia (UFRA), Belém, Pará $\left(1^{\circ} 28^{\prime} \mathrm{S} 48^{\circ \circ} 27^{\prime} \mathrm{W}\right)$. In this region, the climate type is Afi (Köppen), comprising a rainier season between January and June, and a less rainy season from July to December, and an average annual precipitation of $3,001 \mathrm{~mm}$. Local annual average temperature is $26.8^{\circ} \mathrm{C}$, relative humidity is $83 \%$, and sunshine duration is 2,279 hours per year (PACHÊCO et al., 2009).

Four adult male Santa Inês sheep, (mean weight $=54 \mathrm{~kg}$ ) were used in this study. Animals were 
cannulated in the rumen and subjected to a basic diet to meet their maintenance requirements (Table 1). Their diet was composed of $60 \%$ elephant grass 'Napier' (Pennisetum purpureum Schum.) and 40\% Cratylia (C. argentea), and was offered daily at 8:00 a.m. and 2:00 p.m. Mineral salt and drinking water were mixed and served ad libitum in individual troughs and drinking fountains. Animals were kept in individual pens measuring $2.5 \mathrm{~m} \times 3.0 \mathrm{~m}\left(7.5 \mathrm{~m}^{2}\right)$ with $1.1 \mathrm{~m}$ fence during a total experimental period of 21 days, which included 14 days for adaptation to dietary changes and 5 days for data collection. We used the in-situ technique described by Mehrez and Orskov (1977) to determine nutrient degradability of C. argentea, F. macrophylla, and . guianensis 'Campo Grande' (Embrapa).

Table 1. Bromatological composition of the elephant grass cv purple Napier and the leguminous plant Cratylia argentea, used in the experiment as basic dietary foods.

\begin{tabular}{lcccc}
\hline \multirow{2}{*}{ Plant } & \multicolumn{4}{c}{ Nutrient (\%) } \\
\cline { 2 - 4 } & DM & CP & NDF & ADF \\
\hline Elephant grass cv purple Napier & 28.5 & 8.2 & 65.8 & 58.9 \\
Cratylia argentea & 32.8 & 21.9 & 72.5 & 63.6 \\
\hline
\end{tabular}

DM: dry matter; CP: crude protein, NDF: neutral detergent fiber, ADF: acid detergent fiber.

These plants were cut off at $0.3 \mathrm{~m}$ from the soil in rainy season and leaves were selected and pre-dried in a ventilated oven at $55^{\circ} \mathrm{C}$ for $72 \mathrm{~h}$. Subsequently, they were ground to a particle size of $4 \mathrm{~mm}$. Approximately $5 \mathrm{~g}$ of each tested leguminous plant aged 55 and 75 days were placed into nylon bags measuring $10 \times 15 \mathrm{~cm}$ of free area with 50 microns porosity, achieving an approximate ratio of $20 \mathrm{mg} / \mathrm{cm}^{2}$. These bags were incubated during 0,12 , $24,36,48,72$, and $96 \mathrm{~h}$ in triplicates per animal and incubation time, always in the morning (NOCEK, 1988).
Dry matter (DM), crude protein (CP), ethereal extract (EE), neutral detergent fiber (NDF), acid detergent fiber (ADF), ashes (ASH), and lignin contents of the incubated samples and residues were determined according to AOAC International (1995). Neutral detergent insoluble nitrogen (NDIN), acid detergent insoluble nitrogen (ADIN), and lignin indigestible in acid fiber (LIAF) were determined by nitrogen content analysis in residues from direct NDF and ADF determinations, according to the recommendations by Silva and Queiroz (2006) (Table 2). 
Table 2. Bromatological composition of the tropical leguminous plants Cratylia argentea, Flemingia macrophylla (Willd.) Merrill, and Stylosanthes guianensis cv Campo Grande (EMBRAPA), aged 55 and 75 days.

\begin{tabular}{lccccccccc}
\hline \multirow{2}{*}{\multicolumn{1}{c}{ Leguminous plant (age) }} & \multicolumn{10}{c}{ Nutrient (\% in DM) } \\
\cline { 2 - 10 } & DM & CP & EE & NDF & ADF & LIAF & ASH & NIND & NIAD \\
\hline Cratylia argentea (55 days) & 19.32 & 27.62 & 4.64 & 63.3 & 55.61 & 15.01 & 1.27 & 17.13 & 11.22 \\
Cratylia argentea (75 days) & 22.65 & 22.42 & 3.07 & 65.92 & 56.59 & 19.97 & 1.86 & 19.01 & 12.51 \\
Flemingia macrophylla (55 days) & 23.66 & 19.59 & 3.14 & 68.78 & 62.05 & 35.99 & 1.93 & 14.25 & 12.54 \\
Flemingia macrophylla (75 days) & 26.3 & 16.81 & 3.02 & 71.9 & 67.45 & 39.41 & 1.84 & 17.01 & 14.89 \\
Stylosanthes Campo Grande (55 days) & 27.22 & 17.53 & 2.46 & 64.98 & 59.24 & 19.41 & 1.27 & 8.65 & 5.59 \\
Stylosanthes Campo Grande (75 days) & 29.75 & 14.12 & 2.02 & 68.62 & 61.42 & 27.77 & 1.36 & 7.55 & 6.47 \\
\hline
\end{tabular}

DM: dry matter; CP: crude protein, EE: ethereal extract, NDF: neutral detergent fiber, ADF: acid detergent fiber; LIAF: lignin indigestible in acid fiber; ASH: ashes; NIND: nitrogen insoluble in neutral detergent; NIAD: nitrogen insoluble in acid detergent.

Weight loss at each incubation time was probably caused by nutrient disappearance. DM and CP ruminal degradation were adjusted using the degradability model suggested by Orskov and McDonald (1979), as follows: DEG (t) $=a+b$ $\left(1-\mathrm{e}^{-\mathrm{ct}}\right)$, where DEG: accumulated degradability of the nutritional component, after some time t; $\mathbf{a}=$ intercept of the degradability curve, when $\mathrm{t}=0$, corresponding to the soluble fraction of the nutritional component; $\mathbf{b}=$ potential degradability of insoluble but potentially degradable fraction of the nutritional component; $\mathbf{c}=$ degradation rate by fermentative action of the fraction, and $\mathbf{t}=$ incubation time (h). Potential degradability (PD), which is the maximum degradability achieved if food remains in the rumen for indeterminate time, corresponds to the sum a + b. In this study, Kd values corresponds to the residual fraction found in the nylon bag after incubation period in the rumen (undegradable fraction).

The model by Mertens and Loften (1980) was used for NDF ruminal degradation: $\mathrm{Rt}=\mathrm{B} \times \mathrm{e}^{-\mathrm{ct}}+\mathrm{I}$, where $\mathrm{Rt}=$ fraction degraded in time $\mathrm{t} ; \mathrm{B}=$ insoluble fraction potentially degradable, and $\mathrm{I}=$ indigestible fraction. After adjusting this equation for NDF degradation, fractions were standardized according to Waldo et al. (1972), using the equations: $\mathrm{Bp}=$ $\mathrm{B} /(\mathrm{B}+\mathrm{I}) \times 100 ; \mathrm{Ip}=\mathrm{I} /(\mathrm{B}+\mathrm{I}) \times 100$, where: Bp $=$ standardized potentially degradable fraction $(\%)$;
Ip = standardized indigestible fraction (\%); B = insoluble fraction potentially degradable, and $\mathrm{I}=$ as defined above.

The equation proposed by Orskov and McDonald (1979) was used to calculate the effective DM and $\mathrm{CP}$ ruminal degradability of the nutritional component (ED): $E D=a+(b * c / c+k)$, where $a$, $\mathrm{b}$, and $\mathrm{c}=$ as defined above; $\mathrm{k}=$ ruminal passage rate $(\% / \mathrm{h})$. Passage rates of 2,5 and $8 \%$ per hour were adopted for this calculation, as suggested by AFRC (1993). The model by Waldo et al. (1972) was used to calculate ED for NDF, according to the equation $\mathrm{ED}=\mathrm{Bp} * \mathrm{c} /(\mathrm{c}+\mathrm{k})$, where: $\mathrm{Bp}$ is the standardized potentially degradable fraction (\%); c and $\mathrm{k}=$ as defined above. Data were expressed as means and standard deviation, and the statistical treatment was performed using SAS v.9.2 software (SAS Institute, Cary, NC, USA). Means were compared using the PROC GLM procedure and a Tukey's HSD test with $5 \%$ probability.

\section{Results and Discussion}

The "a" fraction represents the water-soluble fraction of food, estimated by the particles eliminated through a nylon bag mesh when immersed in ruminal liquid and then washed in running water (TONISSI et al., 2004). In the present study, C. argentea at both ages, and F. macrophylla aged 55 days 
presented the highest " $a$ " fraction for DM (Table 3). This could be attributed to higher CP levels in these plants, leading to a greater amount of nitrogen available in the rumen, which is quickly used by ruminal microorganisms to produce microbial protein. In addition, a high "a" fraction rate in these leguminous plants can show the presence of higher amounts of soluble carbohydrates such as starch and monosaccharides, which are present in plant cells. Notably, the soluble "a" fraction can contribute to ruminal synthesis of volatile fatty acids, considered the main source of energy for ruminants (SÁ et al., 2011). Stylosanthes aged 55 days presented a lower soluble "a" fraction than the other studied plants (13.26\%). However, according to Oliveira et al. (2014), values above $10 \%$ are considered high.

As expected, all water-soluble fractions values for NDF were zero, since the NDF fraction is insoluble in water. These results differ from those found by Molina et al. (2003), who evaluated ruminal degradability of sorghum silage and reported an "a" fraction value of $23 \%$ for NDF, probably due to the loss of minute particles when the nylon bags were washed at time zero.

Cratylia aged 55 days, and Stylosanthes at both ages, showed the highest "a" fraction values for soluble CP. These high rates obtained for the leguminous plants evaluated and the different "a" fraction degradability values agree with those from Broderick (1995), who reported that leguminous forage has high ruminal degradation rate for $\mathrm{CP}$, and that there are different $\mathrm{CP}$ degradability levels among different leguminous plants. However, the lower degradability level results obtained for some plants are attributed (1) to tannin condensation, which has the property of binding to $\mathrm{CP}$ and carbohydrates; (2) to the protein complexed with lignocellulose, which affects cellulolytic microorganisms; and (3) to the protection against protein degradation by the ruminal microbiota (GODOY, 2007; ABDALLA et al., 2008; OLIVEIRA et al., 2009).

Table 3. Dry matter (DM), neutral detergent fiber (NDF), and crude protein (CP) ruminal degradation parameters of tropical legumes for 2,5 , and $8 \%$ passage rates and coefficient of variation $(\mathrm{CV})$.

\begin{tabular}{|c|c|c|c|c|c|c|c|c|}
\hline \multirow{3}{*}{ Legume/Age (days) } & \multicolumn{8}{|c|}{ DM } \\
\hline & \multicolumn{4}{|c|}{ Fraction (\%) } & \multicolumn{4}{|c|}{$\operatorname{ED}(\% / h)$} \\
\hline & $\mathrm{a}(\%)$ & $\mathrm{b}(\%)$ & $\mathrm{c}(\% / \mathrm{h})$ & $\mathrm{Kd}(\%)$ & PD & $2(\% / h)$ & $5(\% / h)$ & $8(\% / h)$ \\
\hline Cratylia/55 & $24.24 \mathrm{a}$ & $35.74 \mathrm{~b}$ & $2.63 b$ & $40.03 b$ & $54.42 \mathrm{a}$ & $42.89 \mathrm{c}$ & $35.55 \mathrm{~b}$ & $32.44 \mathrm{c}$ \\
\hline Cratylia/75 & $27.80 \mathrm{a}$ & $37.18 b$ & $7.23 \mathrm{a}$ & $35.03 b$ & $64.82 \mathrm{a}$ & $56.59 \mathrm{a}$ & $49.46 \mathrm{a}$ & $45.21 \mathrm{a}$ \\
\hline Flemingia/55 & $23.39 \mathrm{a}$ & $13.13 \mathrm{c}$ & $4.1 \mathrm{~b}$ & $63.49 \mathrm{a}$ & $34.92 \mathrm{c}$ & $31.26 \mathrm{~d}$ & $28.66 \mathrm{~b}$ & $27.41 \mathrm{c}$ \\
\hline Flemingia/75 & $15.85 b c$ & $16.71 \mathrm{c}$ & $5.7 \mathrm{a}$ & $67.45 \mathrm{a}$ & $33.46 \mathrm{c}$ & $28.17 \mathrm{~d}$ & $24.71 \mathrm{c}$ & $22.78 \mathrm{a}$ \\
\hline Stylosanthes/55 & $13.26 \mathrm{c}$ & $51.27 \mathrm{a}$ & $3.8 b$ & $35.48 b$ & $62.76 \mathrm{a}$ & $46.48 b c$ & $35.12 b$ & $29.56 c$ \\
\hline Stylosanthes/75 & $18.66 \mathrm{~b}$ & $42.22 b$ & $7.5 \mathrm{a}$ & $40.12 b$ & $59.54 \mathrm{a}$ & $51.29 \mathrm{ab}$ & $43.46 \mathrm{a}$ & $38.68 b$ \\
\hline \multirow[t]{2}{*}{$\mathrm{CV}$} & 10.02 & 8.67 & 32.5 & 6.01 & 5.62 & 7.33 & 8.49 & 8.32 \\
\hline & \multicolumn{8}{|c|}{ NDF } \\
\hline Cratylia/55 & 0 & $53.79 \mathrm{~b}$ & $2.54 \mathrm{a}$ & $46.21 b c$ & $48.82 \mathrm{a}$ & $29.94 a$ & $18.03 a$ & $12.91 \mathrm{ab}$ \\
\hline Cratylia/75 & 0 & $59.11 \mathrm{a}$ & $4.85 \mathrm{a}$ & $40.91 \mathrm{c}$ & $46.42 \mathrm{a}$ & $38.98 \mathrm{a}$ & $26.68 \mathrm{a}$ & $20.55 \mathrm{a}$ \\
\hline Flemingia/55 & 0 & $29.42 \mathrm{c}$ & $3.54 \mathrm{a}$ & $70.58 \mathrm{a}$ & $25.54 \mathrm{~b}$ & $17.13 b$ & $11.27 \mathrm{~b}$ & $8.48 \mathrm{~b}$ \\
\hline Flemingia/75 & 0 & $30.95 \mathrm{c}$ & $2.38 \mathrm{a}$ & $69.05 \mathrm{a}$ & $26.92 b$ & $16.41 \mathrm{~b}$ & $9.78 b$ & $6.99 b$ \\
\hline
\end{tabular}

continue 
continuation

\begin{tabular}{lcccccccc} 
Stylosanthes/55 & 0 & $58.71 \mathrm{a}$ & $4.28 \mathrm{a}$ & $41.29 \mathrm{c}$ & $56.74 \mathrm{a}$ & $38.95 \mathrm{a}$ & $26.22 \mathrm{a}$ & $19.85 \mathrm{a}$ \\
Stylosanthes/75 & 0 & $50.85 \mathrm{~b}$ & $4.49 \mathrm{a}$ & $49.15 \mathrm{~b}$ & $49.85 \mathrm{a}$ & $34.84 \mathrm{a}$ & $23.79 \mathrm{a}$ & $18.09 \mathrm{a}$ \\
CV & - & 5.73 & 53.74 & 5.11 & 8.98 & 17.29 & 27.91 & 34.14 \\
\hline \multicolumn{7}{c}{$\mathbf{C P}$} \\
\hline Cratylia/55 & $55.07 \mathrm{ab}$ & $28.74 \mathrm{a}$ & $3.62 \mathrm{~b}$ & $15.09 \mathrm{c}$ & $82.81 \mathrm{a}$ & $73.63 \mathrm{~b}$ & $67.40 \mathrm{~b}$ & $64.47 \mathrm{~b}$ \\
Cratylia/75 & $54.95 \mathrm{~b}$ & $27.53 \mathrm{a}$ & $4.53 \mathrm{~b}$ & $17.53 \mathrm{c}$ & $81.42 \mathrm{a}$ & $73.35 \mathrm{~b}$ & $67.51 \mathrm{~b}$ & $64.55 \mathrm{~b}$ \\
Flemingia/55 & $42.71 \mathrm{c}$ & $14.94 \mathrm{bc}$ & $1.53 \mathrm{~b}$ & $42.35 \mathrm{~b}$ & $54.02 \mathrm{~b}$ & $49.09 \mathrm{c}$ & $46.18 \mathrm{c}$ & $45.09 \mathrm{c}$ \\
Flemingia/75 & $26.34 \mathrm{~d}$ & $13.33 \mathrm{c}$ & $2.23 \mathrm{~b}$ & $60.34 \mathrm{a}$ & $37.89 \mathrm{c}$ & $33.24 \mathrm{~d}$ & $30.39 \mathrm{~d}$ & $29.21 \mathrm{~d}$ \\
Stylosanthes $/ 55$ & $65.66 \mathrm{a}$ & $19.15 \mathrm{~b}$ & $5.54 \mathrm{~b}$ & $15.18 \mathrm{c}$ & $84.07 \mathrm{a}$ & $78.85 \mathrm{a}$ & $74.97 \mathrm{a}$ & $72.93 \mathrm{a}$ \\
Stylosanthes/75 & $58.76 \mathrm{ab}$ & $24.84 \mathrm{a}$ & $14.84 \mathrm{a}$ & $16.41 \mathrm{c}$ & $83.44 \mathrm{a}$ & $77.16 \mathrm{ab}$ & $72.56 \mathrm{a}$ & $69.18 \mathrm{ab}$ \\
CV & 9.22 & 11.49 & 48.13 & 8.87 & 3.29 & 3.79 & 4.11 & 3.83 \\
\hline
\end{tabular}

Means followed by different letters in the same line differ among themselves by the Tukey test at $5 \%$ probability. $\mathrm{a}=$ soluble fraction of the nutritional component; $\mathrm{b}=$ potential degradability of the insoluble but potentially degradable fraction of the nutritional component; $\mathrm{c}=$ degradation rate; $\mathrm{Kd}=$ undegradable fraction; $\mathrm{PD}=$ potential degradability; $\mathrm{ED}=$ effective degradability.

The " $b$ " fraction corresponds to the insoluble but potentially degradable portion of the nutritional component. The highest value of " $b$ " for DM was $51.27 \%$ in Stylosanthes 'Campo Grande' (Embrapa) aged 55 days, which shows that this plant has good nutritional potential. The other plants presented lower values for this fraction, with Flemingia showing only 13.13 and $16.71 \%$ aged 55 and 75 days, respectively. This is probably due to the high contents of NDF, ADF, NIND, NIAD, and LIAF fibrous fractions, which can interfere in its degradability. Flemingia also showed high lignin in acid fiber (LIAF) levels at 55 (35.99\%) and 75 (39.41\%) days. These values are higher than those for Cratylia (19.97\% and 27.77\%) at the same ages.

C. argentea at 75 days and Stylosanthes at 55 days showed a higher percentage of potentially degradable "b" fraction for NDF, with 59.11 and $59.71 \%$, respectively. The insoluble "b" fraction values for NDF in Flemingia were 29.42\% and $30.95 \%$, at 55 and 75 days, respectively. These values are considered low when compared to Cratylia and Stylosanthes aged 55 and 75 days, probably because of lower ruminal degradation, showing that these plants' cell wall components compromise insoluble "b" fraction degradation.

The highest " $b$ " fraction values for CP degradability kinetics were found in C. argentea, at both ages, with $28.74 \%$ and $27.53 \%$, and Stylosanthes at 75 days, with $24.84 \%$ of potentially degradable fraction. It can be inferred that Stylosanthes presents a high " $b$ " fraction degradation rate for DM, NDF, and CP, being potentially degradable in the rumen and able to supply energy, hence providing structural carbohydrates for the cellulolytic bacteria and for the animal.

The highest " $c$ " fraction degradation rate for DM was observed in all three leguminous plants at 75 days. There was no significant difference between the NDF degradation rate and the "c" fraction for $\mathrm{CP}$, detecting the highest value (14.84\%) for Stylosanthes at 75 days (see Table 3). For all plants studied here, DM, CP, and NDF degradation rates agreed with those from NRC (2001), which consider good degradability rates values from 2.0 to $9.2 \%$ / h. However, our results differ for Flemingia at 55 days, which has a "c" fraction below $2 \% / \mathrm{h}$, and for Stylosanthes at 75 days, which showed a "c" fraction higher than $9.2 \% / \mathrm{h}$. This low degradation 
rate for Flemingia could be related to high content of fibrous fractions in cell wall.

Flemingia showed the highest percentages of Kd undegradable fraction for DM and NDF at both ages, and for $\mathrm{CP}$ at 75 days. suggesting that ruminal degradation is difficult in this plant Flemingia has high values of fibrous fractions and lignification in its chemical composition, what may explain this result. The lower undegradable fraction values for DM, NDF, and CP in Cratylia and Stylosanthes at both ages suggest that these plants are easily digestible in the rumen, and can contribute to microbial protein synthesis.

The highest PD values for DM, NDF, and CP were found in Cratylia and Stylosanthes at both ages, showing that these plants achieve maximum degradability if food remains in the rumen for indeterminate time. Low PD values for Flemingia can be associated with high fiber content in its bromatological composition, limiting its potential degradation in the rumen. These chemical composition and degradation characteristics restrict the use of Flemingia as a protein bank and supplement in the diet of ruminants.

Depending on the size of food particles after rumination, they can enter the posterior compartment before being fully degraded ("passage rate"). PD was calculated by the equation proposed by Orskov and McDonald (1979), and was estimated without considering the passage rate, which can lead to an overestimated ruminal degradability (PIRES et al., 2006). Therefore, it was necessary to calculate ED, considering passage rates of 2,5 , and $8 \%$ per hour. $\mathrm{ED}$ is related to the energy produced in the rumen, thus, higher ED for DM, NDF, and CP provide higher energy content for ruminal microorganisms (AROEIRA, 1996).

In this study, Cratylia and Stylosanthes aged 75 days showed similar and higher ED values for $\mathrm{DM}$ at 2 and 5\%/hour, compared to Flemingia at both ages, showing that, with degradation rates of 2 and $5 \% / \mathrm{h}$, these plants are more rapidly used by rumen microorganisms to produce energy. Ladeira et al. (2002) reported a similar ED for DM at 5\%/h passage rate with $S$. guianensis hay. ED at $8 \%$ /hour was higher for Cratylia and Flemingia at 75 days, 45.21 and $22.78 \%$ /hour, respectively. ED for NDF in Cratylia and Stylosanthes at both ages had the highest values at all passage rates. Stylosanthes stood out at both ages, with higher ED for CP, regardless of the studied passage rates.

Despite of the relatively high fibrous fraction values for NDF, ADF, NIND, NIAD, and LIAF in Clatylia argentea and $S$. guianensis, these plants do not seem to interfere negatively in potential DM, CP, and NDF degradability values. These values tend to present decreasing results due to different plant ages, with consequent higher LIAF content. Santos et al. (2009) studied Cratylia with high lignified content (30\%), and showed that it did not interfere in consumption and DM, CP, and NDF digestibility.

\section{Conclusions}

Leguminous plants Cratylia and Stylosanthes have high degradation rates in "a" and " $b$ " fractions of CP, and "b" fraction of NDF, and they can be recommended as a protein bank and supplement for ruminants. However, F. macrophylla (Willd.) Merrill should be avoided as a supplementary protein source for ruminants because of its high values of fibrous fractions, with difficult DM, CP, and NDF degradation.

\section{References}

ABDALLA, A. L.; SILVA FILHO, J. C.; GODOI, A. R.; CARMO, C. A. C.; EDUARDO, J. L. P. Utilização de subprodutos de biodiesel na alimentação de ruminantes. Revista Brasileira de Zootecnia, Viçosa, MG, v. 37, p. 260-268, 2008. Suplemento Especial.

AGRICULTURAL AND FOOD RESEARCH COUNCL - AFRC. Technical committee on responses to nutrients: energy and protein requirements of ruminants. Wallingford: Commonwealth Agricultural Bureaux International, $1993.159 \mathrm{p}$. 
AROEIRA, L. J. M.; LOPES, F. C. F.; DAYREL, M. S. Degradabilidade de alguns alimentos no rúmen de vacas Holandês/Zebu. Revista da Sociedade Brasileira de Zootecnia, Viçosa, MG, v. 25, n. 6, p. 1178-1186, 1996.

ASSOCIATION OF OFFICIAL ANALYTICAL CHEMISTS - AOAC. Official methods of analysis. $16^{\text {th }}$ ed. Arlington: AOAC International, 1995. 143 p.

BRODERICK, G. A. Desirable characteristics of forage legumes for improving protein utilization in ruminants. Journal Animal Science, Champaign, v. 73, n. 9, p. 27602773, 1995.

FOOD AND AGRICULTURE ORGANIZATION OF THE UNITED NATIONS - FAO. F. Production: live animals, livestock primary, livestock processed; trade: coutries by commodity (imports and exports). Roma: FAO Library, 2014. Available at: <http://faostat3.fao.org/ browse/Q/QA/S>. Accessed at: 13 dec. 2017.

GODOY, P. B. Aspectos nutricionais de compostos fenólicos em ovinos alimentados com leguminosas forrageiras. 2007. Tese (Doutorado em Ciências) Universidade de São Paulo, Piracicaba.

INSTITUTO BRASILEIRO DE GEOGRAFIA E ESTATÍSTICA - IBGE. Produção da pecuária municipal. Rio de Janeiro: Ministério do Planejamento e Gestão, IBGE, 2016. v. 44.

LADEIRA, M. M.; RODRIGUEZ, N. M.; BORGES, I.; GONÇALVES, L. C.; SALIBA, E. O. S.; MIRANDA, L. F. Balanço de nitrogênio, degradabilidade de aminoácidos e concentração de ácidos graxos voláteis no rúmen de ovinos alimentados com feno de Stylosanthes guianensis. Revista Brasileira de Zootecnia, Viçosa, MG, v. 31, n. 6, p. 2357-2363, 2002.

MEHREZ, A. Z.; ORSKOV, E. R. Rate of rumen fermentation in relation to ammonia concentration. Journal British Nutrition, Southampton, v. 38, n. 3, p. 437-443, 1977.

MERTENS, D. R.; LOFTEN, J. R. The effects of starch on forage fiber digestion kinetics in vitro. Journal of Dairy Science, Champaign, v. 63, n. 9, p. 1437-1446, 1980.

MOLINA, L. R.; RODRIGUEZ, N. M.; SOUZA, B. M.; GONÇALVES, L. C.; BORGES, I. Parâmetros de degradabilidade potencial na matéria seca e da proteína bruta das silagens de seis genótipos de sorgo (Sorghum bicolor (L.) Moench), com e sem tanino no grão avaliados pela técnica in situ. Revista Brasileira de Zootecnia, Viçosa, MG, v. 32, n. 1, p. 222-228, 2003.

MONTEIRO, E. M.; LOURENÇO JUNIOR, J. B.; SANTOS, N. F. A.; AVIZ, M. A. B. Valor nutritivo da leguminosa Pueraria phaseoloides como alternativa na suplementação alimentar de ruminantes na Amazônia Oriental. Ciência Rural, Santa Maria, v. 39, n. 2, p. 613618, 2009.

NATIONAL RESEARCH COUNCIL - NRC. Nutrient requirements of dairy cattle. $7^{\text {th }}$ ed. Washington: Academic Press, 2001. 381 p.

NOCEK, J. E. In situ and other methods to estimate ruminal protein and energy digestibility: a review. Journal of Dairy Science, Champaign, US, v. 71, n. 8, p. 2051-2069, 1988.

OLIVEIRA, E. R.; MONÇÃO, F. P.; GORDIN, C. L.; GABRIEL, A. M. A.; LEMPP, B.; SANTOS, M. V.; REIS, S. T.; MOURA, L. V. Degradabilidade ruminal da matéria seca de folhas e colmo de genótipos de Cynodon spp. em quatro idades de rebrota. Semina: Ciências Agrárias, Londrina, v. 35, n. 5, p. 2659-2672, 2014.

OLIVEIRA, S. G.; BERCHIELLI, T. T.; PEDREIRA, M. S.; FERNANDES, J. J. R.; PIRES, A. V. Degradação ruminal e síntese de proteína microbiana em bovinos alimentados com silagem de sorgo contendo tanino suplementado com concentrado ou uréia. Acta Scientiarum. Animal Sciences, Maringá, v. 31, n. 1, p. 45-51, 2009.

ORSKOV, E. R.; McDONALD, I. The estimation of protein degradability in the rumen from incubation measurements weighted according to rate of passage. Journal of Agricultural Science, Cambridge, v. 92, n. 2, p. 499-503, 1979.

PACHÊCO, N. A.; SANTIAGO, A. V.; BASTOS, T. X.; CORDEIRO, A. H. F. Boletim agrometeorológico de 2009 para Belém, PA. Belém: EMBRAPA Amazônia Oriental, 2009. (Documentos, 371).

PIRES, A. J. V.; REIS, R. A.; CARVALHO, G. G. P.; SIQUEIRA, G. R.; BERNARDES, T. F.; RUGGIERI, A. C.; ALMEIDA, E. O.; ROTH, M. T. P. Degradabilidade ruminal da matéria seca, da fração fibrosa e da proteína bruta de forrageiras. Pesquisa Agropecuária Brasileira, Brasília, v. 41, n. 4, p. 643-648, 2006.

SÁ, J. F.; PEDREIRA, M. S.; SILVA, F. F.; FIGUEIREDO, M. P. F.; REBOUÇAS, M. N.; SOUZA, D. R. Cinética da fermentação in vitro do capim-Marandu em diferentes idades de corte. Acta Scientiarum. Animal Sciences, Maringá, v. 33, n. 3, p. 225-231, 2011.

SANTOS, N. F. A.; LOURENÇO JÚNIOR, J. B.; ARAÚJO, C. V.; MONTEIRO, E. M. M.; GARCIA, A. R.; NAHUM, B. S. Efeitos dos níveis de substituição de quicuio-da-amazônia (Brachiaria humidicola) por Cratylia argentea sobre o consumo e digestibilidade aparente em ovinos. Amazônia: Ciência \& Desenvolvimento, Belém, v. 4, n. 8, p. 141-160, 2009. 
SILVA, D. J.; QUEIROZ, A. C. Análise de alimentos: métodos químicos e biológicos. 3. ed. Reimpressão. Viçosa, MG: UFV, Imprensa Universitária, 2006. 235 p.

TONISSI, R. H.; GOES, B.; MANCIO, A. B. Degradação ruminal da matéria seca e proteína bruta, de alimentos concentrados utilizados como suplementos para novilhos. Ciência e Agrotecnologia, Lavras, v. 28, n. 1, p. 167-173, 2004.

WALDO, D. R.; SMITH, L. W.; COX, E. L. Model of cellulose disappearance from the rumen. Journal of Dairy Science, Champaign, US, v. 55, n. 1, p. 125-129, 1972. 
